\title{
Surgical Management of an Extragonadal Trabecular Carcinoid Tumor: A Case Report and Review of the Literature
}

\author{
Emily Hinchcliff ${ }^{*}$, Sophie Cowan ${ }^{2}$, Michelle Forrestall Lee ${ }^{3}$, Esther Oliva ${ }^{3}$ and Annekathryn Goodman ${ }^{1}$ \\ ${ }^{1}$ Department of Obstetrics and Gynecology, Massachusetts General Hospital, USA \\ ${ }^{2}$ Department of Radiology, Massachusetts General Hospital, USA \\ ${ }^{3}$ Department of Pathology, Massachusetts General Hospital, USA
}

\begin{abstract}
Extragonadal malignant transformation of a teratoma is rare, with only six reported cases in the literature. We report a case of a 33-year-old gravida 4 para 2 woman who had incidentally discovered bilateral pelvic masses, which were followed radiographically for nine years. She then underwent surgical resection, which revealed metastatic trabecular carcinoid involving lymph node tissue (left retroperitoneal pelvic mass), and trabecular carcinoid arising in a background of mature teratoma (right presacral mass). This case illustrates the indolent nature of this tumor and the importance of complete surgical resection.
\end{abstract}

Keywords: Extragonadal germ cell tumors; Trabecular carcinoid tumors; Mature teratoma

\section{Introduction}

Malignant extragonadal germ cell tumors can arise anywhere along the gonadal ridge. Locations may include the retroperitoneal, mediastinum, presacral region, and pineal gland [1]. An Extragonadal Germ Cell Tumor (EGCT) is by definition a germ cell neoplasm displaying one of the histologies associated with gonadal origin, but located outside of the gonads [2]. EGCT arise from primordial germ cells that migrate from the yolk sac/endoderm to the genital ridge [3]. The standard treatment for EGCT includes surgery, while chemotherapy or radiotherapy may be added for certain malignant subtypes [4].

Carcinoid tumors are uncommon neoplasms in the diffuse peripheral endocrine system. Ovarian carcinoids are uncommon and primary ovarian carcinoids make up approximately $0.5-1.7 \%$ of all carcinoid tumors [5]. Extragonadal carcinoid tumors are extremely rare with only six reported cases in the literature [6-11]. We report on a patient with a slowly growing pelvic mass observed radiographically over nine years that at surgical excision was found to be an extragonadal trabecular carcinoid.

\section{Case Report}

33-year-old Caucasian female patient, gravida 4 para 2, without other significant past medical history presented in 2014 after the birth of her second child for management of stable bilateral pelvic masses that had been monitored since 2005. Lesions were initially noted as an incidental finding on a CT of abdomen and pelvis performed in the setting of appendicitis in 2005. They were not noted or commented upon in the operative note from a laparoscopic appendectomy performed at that time. They were then re-identified on routine obstetric ultrasound, and were conservatively managed with watchful waiting in the setting of her pregnancy. She had an uncomplicated pregnancy and underwent a primary cesarean section for malpresentation. The retroperitoneal masses were not commented on in the operative report.

Postpartum, she was referred for definitive surgical management and diagnosis. The patient was entirely asymptomatic. She had no irregular bleeding, and no lower extremity or back pain. She experienced constipation and irregular bowel movements for several years. Physical exam was unremarkable, with normal lower extremity motor and sensory nervous systems, and a pelvic exam without obvious palpable adnexal masses.

She underwent a follow-up pelvic MRI in December of 2013 that showed a slight increase in the size of the left sided mass. She then underwent surgical excision in February of 2014. Figure 1 shows the clinical timeline.

\section{Radiology}

Table 1 outlines the radiologic imaging studies. Figure 2 shows ultrasound and CT scan images from 2012. Figure 3 shows the July 2013 axial MRI images of the retroperitoneal position of the masses. Figure 4 shows a sagittal MRI image of the presacral mass from December of 2013.

\section{Surgical Procedure}

A laparoscopic approach was used. The left retroperitoneal space was entered and a $6 \mathrm{~cm}$ mass was identified along the left pelvic sidewall inferior to the ureter (Figure 5). The ureter was identified and fully mobilized and separated from the mass. The feeder vessels from the internal iliac vessels that vascularized the mass were separately isolated and cauterized. The mass was resected completely without rupture and placed in an endoscopic bag and removed.

The right sided retroperitoneal mass was adherent to the right presacral space just superiorly to the cul-de-sac and was densely adherent to the foramina of the sacrum. The mass was inferior and at a distance from the right ureter and right iliac vessels. An incision was made in the peritoneum of the medial leaf of the right broad ligament, inferior to the ureter, and the rectum was mobilized anteriorly. The mass was gently peeled off the sacral nerves and veins using a laparoscopic swab and harmonic cautery. The mass was unruptured and was placed

*Corresponding author: Emily Hinchcliff, Massachusetts General Hospital, 55 Fruit Street Boston, MA 02114, USA, Tel: 607-229-3332; E-mail: ehinchcliff@ partners.org

Received October 27, 2015; Accepted December 17, 2015; Published December 23, 2015

Citation: Hinchcliff E, Cowan S, Lee MF, Oliva E, Goodman A (2015) Surgica Management of an Extragonadal Trabecular Carcinoid Tumor: A Case Report and Review of the Literature. Arch Surg Oncol 1: 103. doi: 10.4172/2471-2671.1000103

Copyright: (C) 2015 Hinchcliff E. This is an open-access article distributed under the terms of the Creative Commons Attribution License, which permits unrestricted use, distribution, and reproduction in any medium, provided the original author and source are credited. 


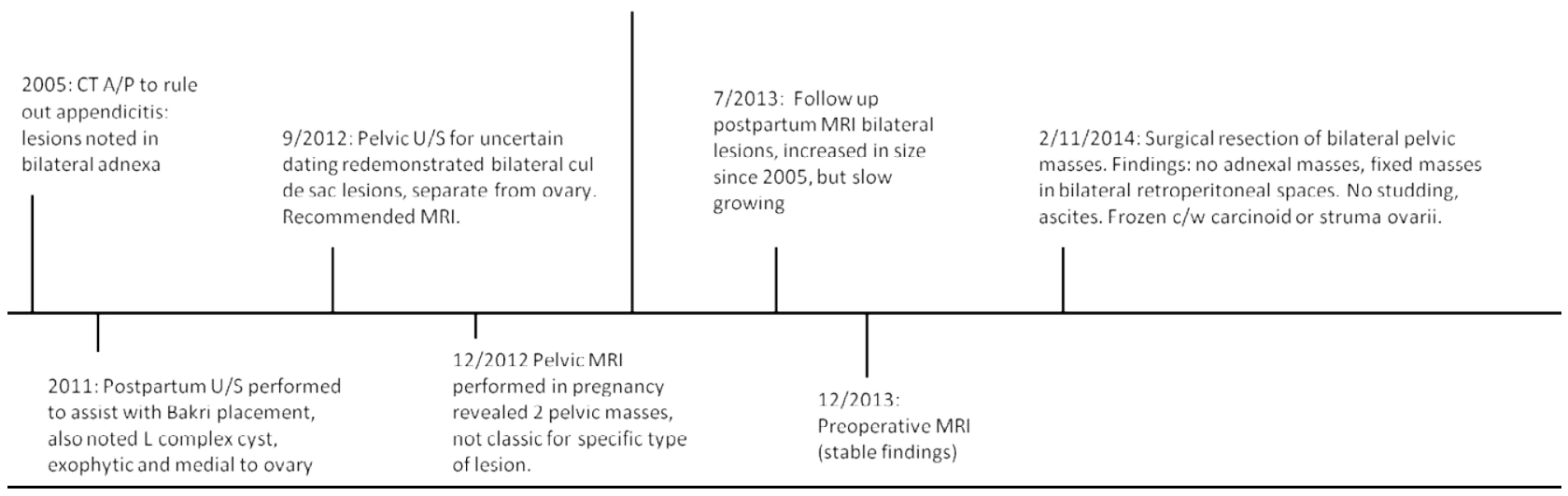

Figure 1: Clinical timeline.
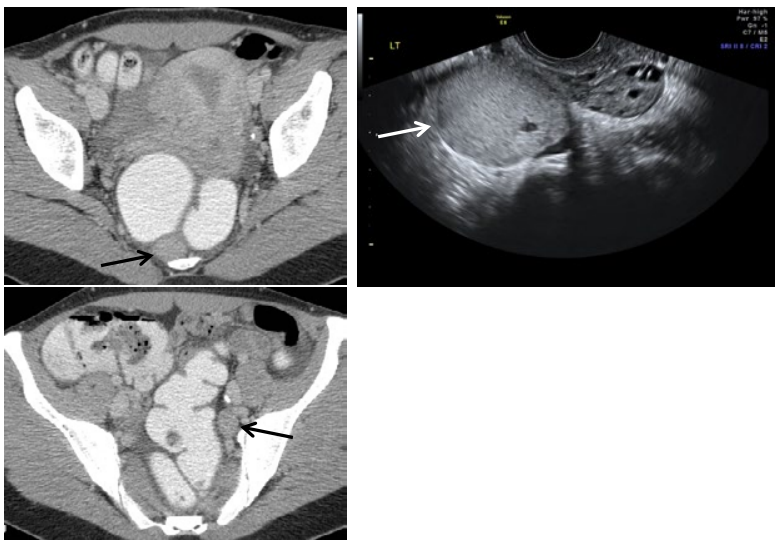

Figure 2: Ultrasound images from September 2012 and CT scan axial images from December 2012

Two axial CT images with contrast (left) demonstrate low attenuation pelvic massess in the right presacral space and the left retroperitoneum (black arrows). Ultrasound images (above) demostrates the left retroperitoneal mass (white arrow) seprate from the adjacent left ovary. Note is made of a small cystic area in the left retroperitoneal mass.

in a laparoscopic bag and removed through the abdominal port site. A sigmoidoscopy was then performed which confirmed that the rectum and sigmoid colon were intact and uninjured by the dissection. The right and left ovaries and fallopian tubes and the uterus were structurally normal. The liver and small and large intestine were also normal to laparoscopic evaluation. The patient tolerated the procedure and was discharged to home on the same day as the surgery.

\section{Pathology}

In 2005, the patient underwent a laparoscopic appendectomy for appendicitis. Pathology showed acute suppurative appendicitis and periappendicitis. There was no evidence of a carcinoid tumor within the appendix.

In 2014, the patient underwent a resection of the right presacral mass and the left retroperitoneal mass. The right presacral mass measured 3.8 by 2.6 by $2.1 \mathrm{~cm}$ and its cut surface showed a $2.2 \times 1.5$ $\times 1 \mathrm{~cm}$ smooth lined cyst containing pink gelatinous material that was surrounded by homogeneous, solid and focally lobulated tan tissue with speckles of hemorrhage (Figure 6). The left retroperitoneal mass measured $6.5 \times 6.2 \times 1.4$ that had a tan soft appearance.
On microscopic evaluation, the left retroperitoneal pelvic mass was felt to be consistent with metastatic trabecular carcinoid involving lymph node tissue, whereas the right presacral mass was consistent with trabecular carcinoid arising in a background of mature teratoma. The cystic portion of the sacral mass was lined by benignappearing mucinous, pseudostratified ciliated and transitional-like epithelium. Scattered islands of fetal cartilage were present (Figure 7). As mentioned, the overall appearance was that of a mature teratoma. However, most of the presacral mass and all the retroperitoneal mass were composed of a trabecular carcinoid in which irregular often anastomosing trabeculae display cells with relatively abundant eosinophilic cytoplasm and homogeneous small oval to round nuclei with "salt and pepper" chromatin (Figure 8). Mitoses were rare. The stroma was typically scant but prominent thin walled blood vessels were frequently found. Only this component of the tumor was positive for neuroendocrine markers including chromogranin, synaptophysin, NSE and CD56 (Figure 9).

\section{Follow-up Clinical Course}

In the initial postoperative period, the patient underwent a full metastatic work-up. Her CA 125 was 7 units/ml (normal range 7-35). Human chorionic gonadotropin was less than $6 \mathrm{mIU} / \mathrm{ml}$. The twentyfour urine 5 hydroxyindole acetic acid (5HIAA) was in the normal range at $2 \mathrm{mg} / 24$ hour. A PET CT scan in August of 2014 was negative for lesions and for metabolic uptake of 2-deoxy-2-[fluorine-18]fluoroD-glucose $\left({ }^{18} \mathrm{~F}\right.$ FDG).

The patient became pregnant in the summer of 2015 but had a pregnancy loss at 20 weeks. At her October 2015 follow-up, twentyone months after the surgical resection of the extragonadal germ cell tumor and the metastases in one contralateral lymph node, the pelvic MRI was negative for masses. The patient is currently in good health and has no complications from the surgical resection.

\section{Discussion}

Extragonadal germ cell tumors have major differences in clinical behavior that suggest EGCT are biologically different from primary gonadal germ cell tumors [2]. For instance, EGCT are much more likely to be bulky at presentation and as with our patient, have metastatic disease.

In one large international review of 635 consecutive patients treated from 1975 through 1996 at 11 cancer centers, 341 patients (54\%) had primary mediastinal EGCT, and 283 patients (45\%) had 
Citation: Hinchcliff E, Cowan S, Lee MF, Oliva E, Goodman A (2015) Surgical Management of an Extragonadal Trabecular Carcinoid Tumor: A Case Report and Review of the Literature. Arch Surg Oncol 1: 103. doi: 10.4172/2471-2671.1000103

Page 3 of 5

\begin{tabular}{|l|l|l|}
\hline Date & Type of scan & Findings \\
\hline September 2005 & CT scan of the pelvis & Low attenuation lesions in the right and left adnexal areas: $2 \mathrm{~cm}$ size \\
\hline September 2011 & Pelvic trans-abdominal ultrasound & Left adnexa: $4.0 \times 3.8 \times 2.9 \mathrm{~cm}$ complex cyst left and medial to ovary \\
\hline September 2012 & Pelvic trans-vaginal ultrasound & $\begin{array}{l}\text { Left cul de sac } 4.5 \times 2.8 \times 4.5 \mathrm{~cm} \text { uniform mass } \\
\text { Right cul de sac } 3.7 \times 2.43 \mathrm{~cm} \text { solid cystic mass }\end{array}$ \\
\hline December 2012 & CT scan of the pelvis & $\begin{array}{l}\text { Left } 4.1 \times 2.9 \times 4.1 \mathrm{~cm} \text { mass anterior to piriformis and posteromedial to iliac vessels } \\
\text { Right presacral space } 2.4 \times 3 \times 4.4 \mathrm{~cm} \text { mass } \\
\text { Normal right and left ovaries }\end{array}$ \\
\hline July 2013 & Pelvic MRI & $\begin{array}{l}\text { Left piriformis muscle } 3 \times 4 \times 3 \mathrm{~cm} \text { complex mass } \\
\text { Right presacral } 3 \times 2.4 \mathrm{~cm} \text { mass } \\
\text { No lymphadenopathy }\end{array}$ \\
\hline December 2013 & Pelvic MRI & $\begin{array}{l}\text { Left mass } 4.6 \times 3.1 \mathrm{~cm} \\
\text { Right mass } 2.7 \mathrm{~cm} \times 2.5 \mathrm{~cm}\end{array}$ \\
\hline
\end{tabular}

Table 1: Radiologic imaging studies from 2005 to 2014 of an extragonadal germ cell tumor.
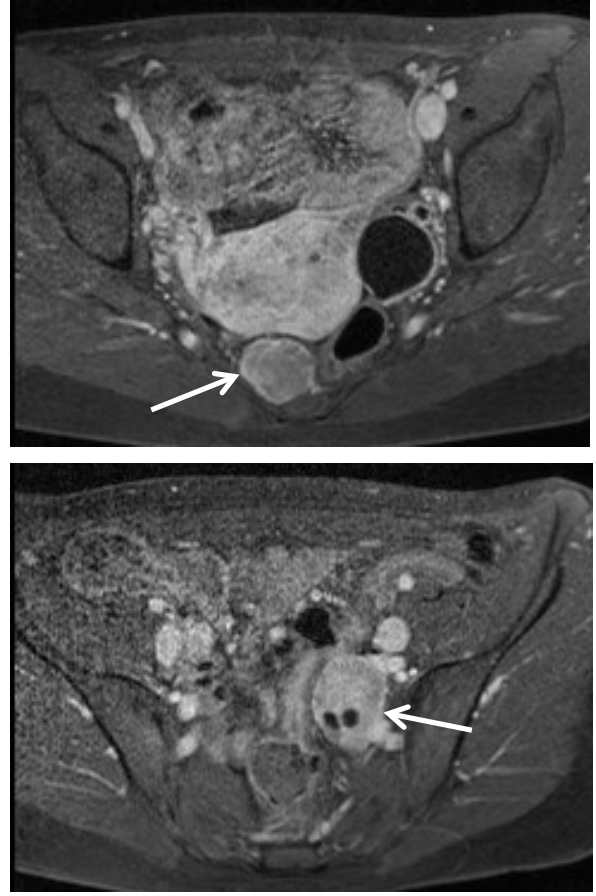

Axial post contrast MRI images demonstrate enhancing pelvic masses in the right presacral space and the left retroperitoneum (white arrows). Two nonenhancing cystic areas are seen in the left retroperitoneal mass (bottom image). Figure 3: Pelvic MRI from July 2013.

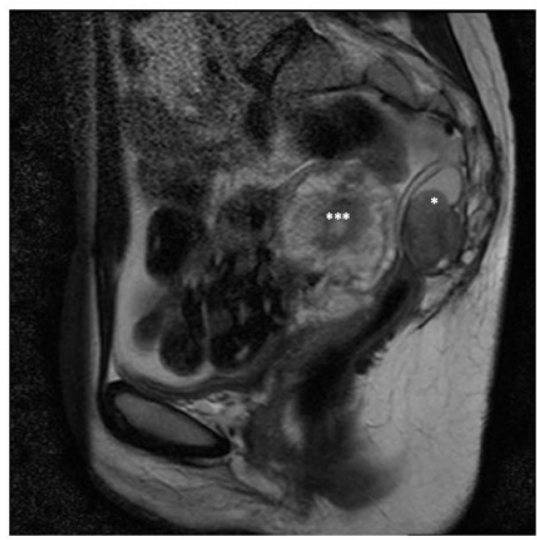

Sagittal MRI image demonstrates presacral mass $\left({ }^{*}\right)$, with uterus also identified $\left({ }^{* * *}\right)$

Figure 4: Pelvic MRI from December 2013.

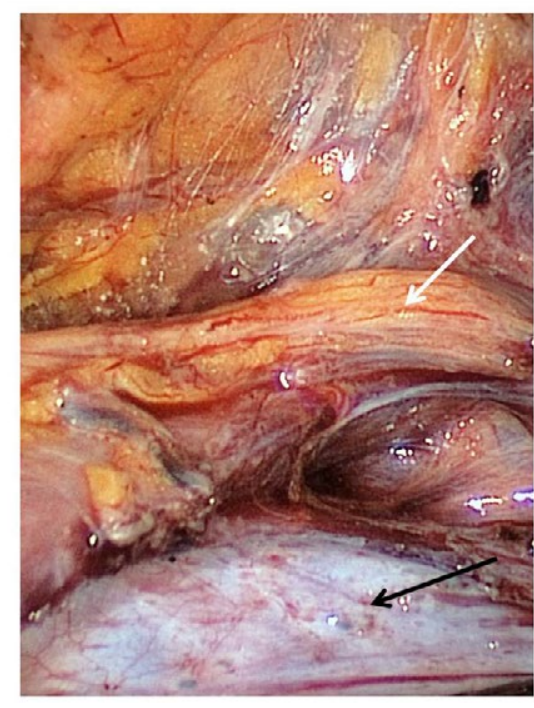

Intraoperative Photograph: Left pelvic sidewall. Ureter (white arrow) has been mobilized superiorly. Retroperitoneal mass (black arow) is inferior to the iliac vessels.

Figure 5: Intraoperative Photograph: Left pelvic sidewall.

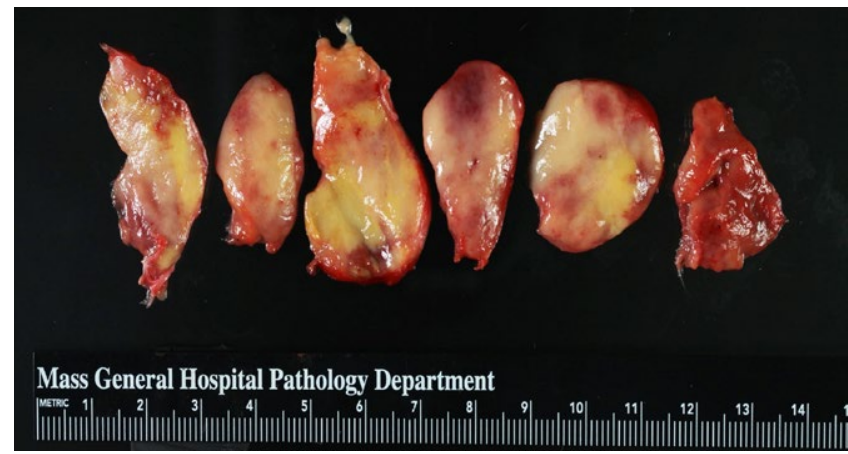

Figure 6: Extragonadal trabecular carcinoid tumor.

retroperitoneal EGCT. Five hundred twenty-four patients (83\%) had a nonseminomatous germ cell tumor (GCT), and 104 patients (16\%) had a seminomatous histology [12].

Malignant germ cell tumors are uncommon, 1-3\% of germ cell tumors, and the majority of these malignancies are embryonal tumors such as dysgerminomas, embryonal carcinomas, or yolk sac tumors [13]. Much more rare is the malignant transformation of the somatic 


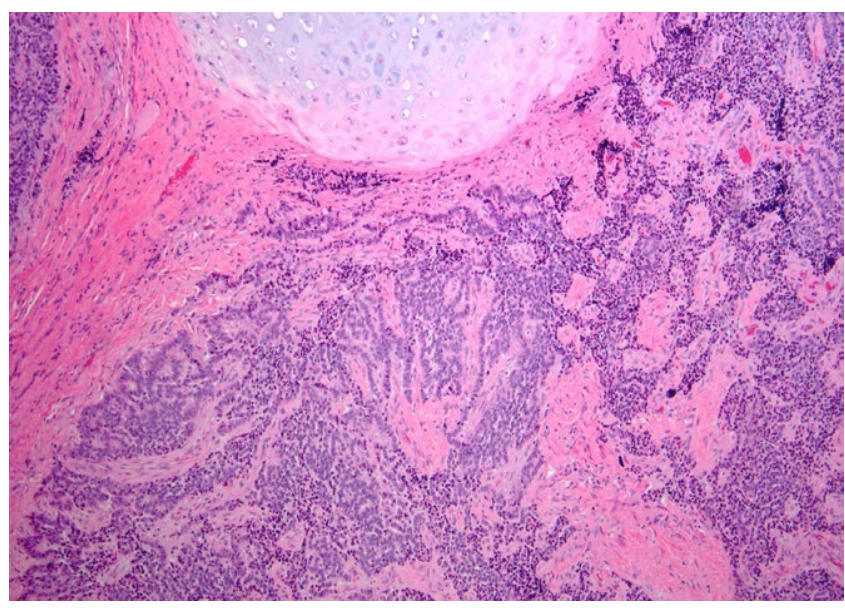

Figure 7: Extragonadal trabecular carcinoid with fetal cartilage at superior portion of photo (Hematoxylin Eosin 10x).

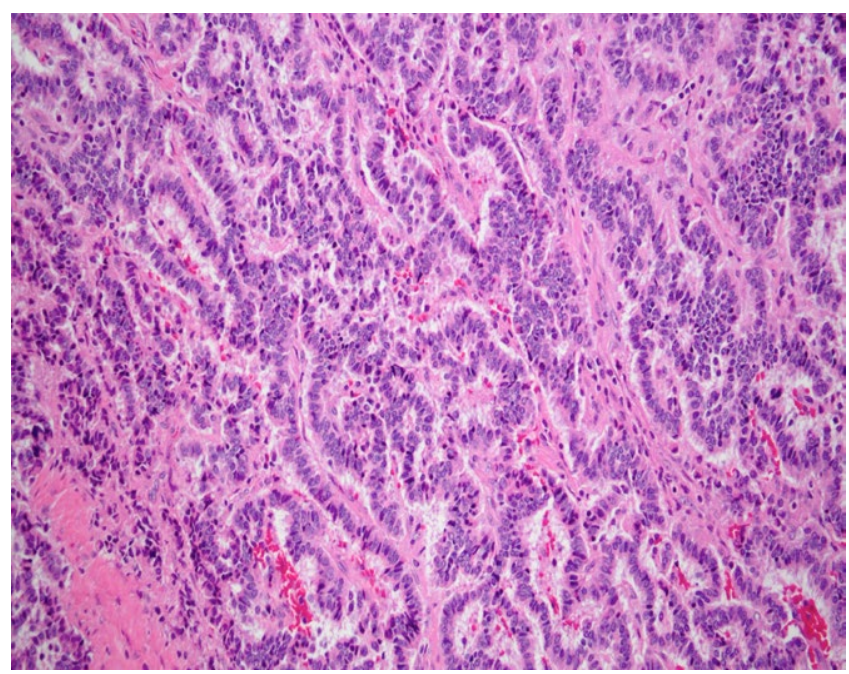

Figure 8: Extragonadal trabecular carcinoid (Hematoxylin Eosin 40x).

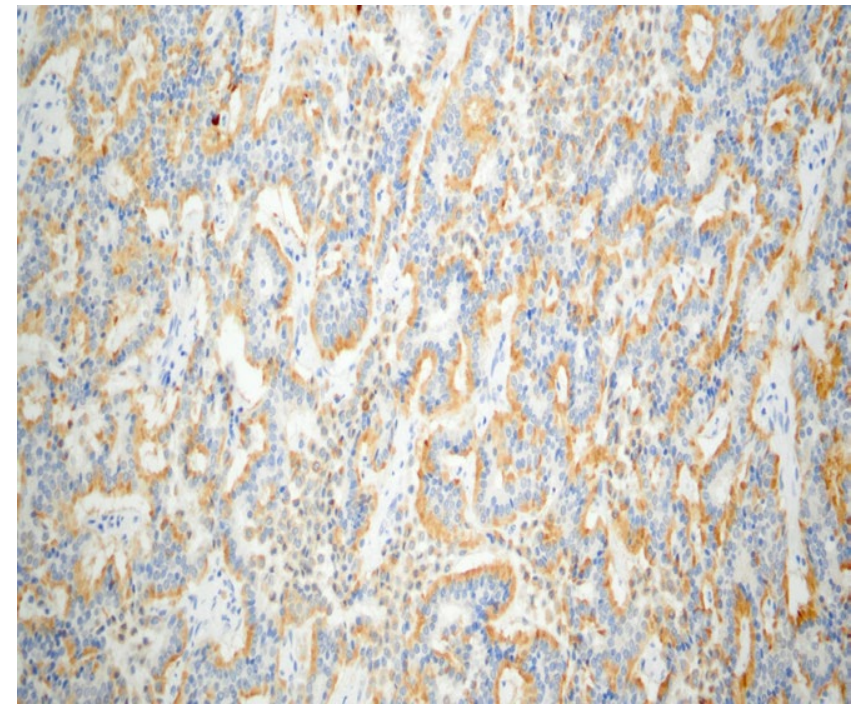

Figure 9: Extragonadal trabecular carcinoid positive for neuroendocrine markers including chromogranin, synaptophysin, NSE and CD56. components of a mature cystic teratoma, of which squamous cell cancer accounts for $70-88 \%$ [14]. Among mature cystic teratomas with malignant transformation, neuroendocrine carcinoid tumors are significantly more rare, with reports in approximately $6 \%$ of all malignant cases [15]. Only six extragonadal carcinoid tumors arising in mature cystic teratomas have been reported in the English literature to date, but none of these cases reported metastatic disease [6-11]. Table 2 summarizes the clinical findings of these individual cases. Our patient's case is the first report of extragonadal malignant transformation with metastasis, found in lymph node tissue.

In the literature, age range varies widely, from 22 to 63 years old (mean 40.8 years), with the most common presenting symptom being abdominal pain or discomfort. Radiologic findings are similar in all cases, with complex cystic and solid tumors. The reported size of these tumors is large, ranging from $5 \mathrm{~cm}$ to $16 \mathrm{~cm}$, with a mean of approximately $11 \mathrm{~cm}$ in largest diameter. In the case presented here, the patient presented initially asymptomatic with a small $2 \mathrm{~cm}$ lesion, which then grew on follow up imaging examination to $3 \mathrm{~cm}$ and was noted to be $6 \mathrm{~cm}$ at surgery. It is possible that these lesions would not have been discovered, had they not been noted on the obstetrical ultrasounds, until they became large enough to cause symptoms.

Classically, as with our patient, these tumors are treated with surgical excision. The role of chemotherapy or radiation has not been established. Two of the six case reports included a referral to chemotherapy $[6,10]$. In carcinoid tumors arising from teratomas of the ovary, treatment can be completed with surgical excision alone, usually salpingo-oophorectomy [16]. There are reports of five-year survival with cystectomy alone for primary ovarian carcinoid malignancies [15]. There was only one case study that reported metastasis from the ovary of the carcinoid element, unsuccessfully treated with thioTEPA [17].

Our patient was treated by a radical retroperitoneal excision using a minimally invasive surgical approach. Given the deeply placed position of extragonadal tumors over major vascular structures and neurovascular bundles, a laparoscopic approach should be encouraged. Laparoscopy offers higher resolution optics, which allows the ability to preserve nerves and blood vessels, with a significant reduction blood loss [18].

Trabecular carcinoids may be difficult to diagnose preoperatively. Our patient had normal tumor markers and a very slow growth of the tumor over a period of 8 years. Other reports also document a lack of tumor markers in this type of tumor [5]. Carcinoid tumors are defined as of neuroendocrine origin and have been classified into 3 types: neuroendocrine carcinomas, typical and atypical carcinoids. While neuroendocrine carcinoma is a malignant epithelial neoplasm with high mitotic activity, high nucleoplasmic ratio, necrosis, vascular invasion, high rate of metastasis, and poor prognosis [19], trabecular carcinoids are much more indolent. The typical carcinoid tumor is a low-grade malignant tumor with rare mitotic activity, rare necrosis, monotony of nuclear size and shape, slow growth, and good prognosis. The atypical carcinoid tumor is an intermediate-grade neoplasm generally with punctuated necrosis and intermediate-mitotic activity [20].

Information from large series is instructive to understand behavior and prognosis. An institutional review evaluated 26 ovarian carcinoids and determined that 16 were primary and 10 were metastatic from the gastrointestinal tract [21]. The average size of primary ovarian carcinoids was $3.4 \mathrm{~cm}$ (range: $0.2-13.5 \mathrm{~cm}$ ) versus $10.2 \mathrm{~cm}$ for metastatic carcinoids (range: $4-32 \mathrm{~cm}$ ). Teratomatous elements 
Page 5 of 5

\begin{tabular}{|c|c|c|c|c|c|c|c|}
\hline $\begin{array}{l}\text { Author } \\
\text { year }\end{array}$ & Age & Symptoms & Location & Size $(\mathrm{cm})$ & Treatment & Pathology & Outcome* \\
\hline $\begin{array}{l}\text { Sable } \\
2014\end{array}$ & 35 & Low back pain & Right precoccygeal space & $10 \mathrm{~cm}$ & $\begin{array}{l}\text { Surgical excision } \\
\text { of mass, referral to } \\
\text { chemo }\end{array}$ & $\begin{array}{c}\text { neuroendocrine carcinoma } \\
\text { of intermediate malignant } \\
\text { potential }\end{array}$ & Not reported \\
\hline $\begin{array}{l}\text { Yamasaki } \\
2004\end{array}$ & 53 & Urinary frequency & $\begin{array}{l}\text { Left pararenal } \\
\text { retroperitoneum }\end{array}$ & $\begin{array}{l}12 \\
\mathrm{~cm}\end{array}$ & $\begin{array}{l}\text { Surgical excision of } \\
\text { mass }\end{array}$ & $\begin{array}{c}\text { mature teratoma with a } \\
\text { carcinoid component }\end{array}$ & DF $>31$ months \\
\hline $\begin{array}{l}\text { Arazi } \\
2007\end{array}$ & 63 & Low back pain & $\begin{array}{l}\text { Sacro- } \\
\text { coccygeal, extending to } \\
\text { the distal } \\
\text { sacrum and rectum }\end{array}$ & $5 \mathrm{~cm}$ & $\begin{array}{l}\text { Surgical excision of } \\
\text { mass }\end{array}$ & $\begin{array}{c}\text { neuroendocrine carcinoma } \\
\text { arising within a mature } \\
\text { teratoma }\end{array}$ & $\mathrm{DF}>22 \mathrm{mo}$ \\
\hline $\begin{array}{l}\text { Pendlimari } \\
2010\end{array}$ & 22 & $\begin{array}{l}\text { Pelvic pain, } \\
\text { incontinence }\end{array}$ & Presacral & $6 \mathrm{~cm}$ & $\begin{array}{c}\text { Surgical excision of } \\
\text { mass, meningocele } \\
\text { removal, bilateral iliac } \\
\text { LNs }\end{array}$ & $\begin{array}{l}\text { moderately differentiated } \\
\text { neuroendocrine carcinoma } \\
\text { arising in teratoma }\end{array}$ & $\mathrm{DF}>24 \mathrm{mo}$ \\
\hline $\begin{array}{l}\text { Scott } \\
2010\end{array}$ & 48 & Abdominal pain & $\begin{array}{l}\text { Retroperitoneal between } \\
\text { left adrenal and spleen }\end{array}$ & $\begin{array}{l}15 \\
\mathrm{~cm}\end{array}$ & $\begin{array}{l}\text { Surgery followed by } \\
\text { chemo }\end{array}$ & $\begin{array}{l}\text { Neuroendocrine carcinoma } \\
\text { arising in mature teratoma }\end{array}$ & $\mathrm{DF}>6 \mathrm{mo}$ \\
\hline $\begin{array}{l}\text { Shindo } \\
2013\end{array}$ & 24 & $\begin{array}{c}\text { Asymptomatic mass } \\
\text { on exam }\end{array}$ & $\begin{array}{l}\text { Retroperitoneal between } \\
\text { right liver and kidney }\end{array}$ & $\begin{array}{l}16 \\
\mathrm{~cm}\end{array}$ & Tumor excision & $\begin{array}{l}\text { Ependymoma and } \\
\text { trabecular carcinoid tumor } \\
\text { arising from a mature cystic } \\
\text { teratoma }\end{array}$ & $\mathrm{DF}>24 \mathrm{mo}$ \\
\hline
\end{tabular}

${ }^{*} \mathrm{DF}=$ Disease free

Table 2: Summary of Case reports from the literature.

were present in association with 10/16 primary ovarian carcinoids, whereas none were present in any metastatic carcinoid. The primary ovarian carcinoid types were insular $(n=6)$, trabecular $(n=3)$, strumal $(n=6$, of which 5 were trabecularpattern and 1 was insular pattern) or mucinous $(\mathrm{n}=1)$. All metastatic carcinoids, except for two of mucinous type, were insular [21].

Based on the six previously reported extragonadal carcinoid tumors, the prognosis after excision is excellent [6-11]. Disease-free survival was reported as 6 to 31 months. Our patient has no evidence of recurrence from a metastatic extragonadal carcinoid at 21 months to date.

\section{Conclusion}

1) Malignant transformation in a mature cystic teratoma to a trabecular carcinoid is uncommon, but these tumors are regarded as having a low malignant potential with good prognosis and survival.

2) Extragonadal germ cell tumors are exceedingly rare and are difficult to diagnose without surgery.

3) Complete surgical excision is the treatment of choice. Minimally invasive surgical techniques such as laparoscopic retroperitoneal dissection should be encouraged.

4) This report describes the seventh case of an extragonadal carcinoid tumor and the first case of metastatic disease in a lymph node.

\section{References}

1. Johnson DE, Laneri JP, Mountain CF, Luna M (1973) Extragonadal germ cell tumors. Surgery 73: 85-90.

2. Schmoll HJ (2002) Extragonadal germ cell tumors. European Society for Medical Oncology 2002.

3. Witschi E (1948) Migration of the germ cells of human embryos from the yolk sac to the primitive gonadal folds. Contr Embryol Carnegie Inst 32: 67-80.

4. McLeod DG, Taylor HG, Skoog SJ, Knight RD, Dawson NA, et al. (1988) Extragonadal germ cell tumors. Clinicopathologic findings and treatment experience in 12 patients. Cancer 61: 1187-1191.

5. Bai X, Li N, Wang F, Li S, Yu Q (2010) Primary ovarian trabecular carcinoid tumor: a case report and literature review. Arch Gynecol Obstet 282: 407-411.

6. Sable MN, Nath D, Chumbar S, Das CJ, Priyadarshini P, et al. (2014) Pelvic mature cystic teratoma with neuroendocrine carcinoma: report of a rare association and review of literature. Indian J Pathol Microbiol 57: 113-115.
7. Yamasaki T, Yagihashi Y, Shirahase T, Hashimura T, Watanabe C (2004) Primary carcinoid tumor arising in a retroperitoneal mature teratoma in an adult. Int J Urol 11: 912-915.

8. Arazi M, Toy H, Tavli L (2007) Primary neuroendocrine carcinoma arising within a mature sacrococcygeal teratoma. Orthopedics 30: 878-879.

9. Pendlimari R, Leonard D, Dozois EJ (2010) Rare malignant neuroendocrine transformation of a presacral teratoma in patient with Currarino syndrome. Int $\mathrm{J}$ Colorectal Dis 25: 1383-1384.

10. Scott AL, Abbassi-Ghadi N, Archer CM, Swamy R, Gupta S (2010) Neuroendocrine carcinoma arising within a retroperitoneal mature teratoma. Ann R Coll Surg Engl 92: W5-8.

11. Shindo K, Ueda J, Toubo T, Nakamura M, Oda Y, et al. (2013) Primary carcinoid tumor in a retroperitoneal mature teratoma: report of a case. Surg Today 43: 694-697.

12. Bokemeyer C, Nichols CR, Droz JP, Schmoll HJ, Horwich A, et al. (2002) Extragonadal germ cell tumors of the mediastinum and retroperitoneum: results from an international analysis. J Clin Oncol 20: 1864-1873.

13. Genadry R, Parmley T, Woodruff JD (1979) Secondary malignancies in benign cystic teratomas. Gynecol Oncol 8: 246-251.

14. Kikkawa F, Ishikawa H, Tamakoshi K, Nawa A, Suganuma N, et al. (1997) Squamous cell carcinoma arising from mature cystic teratoma of the ovary: a clinicopathologic analysis. Obstet Gynecol 89: 1017-1022.

15. Davis KP, Hartmann LK, Keeney GL, Shapiro H (1996) Primary ovarian carcinoid tumors. Gynecol Oncol 61: 259-265.

16. Robboy SJ, Scully RE (1980) Strumal carcinoid of the ovary: an analysis of 50 cases of a distinctive tumor composed of thyroid tissue and carcinoid. Cancer 46: 2019-2034.

17. Armes JE, Ostör AG (1993) A case of malignant strumal carcinoid. Gynecol Oncol 51: 419-423.

18. Iserte PP, Minig L, Zorrero C1 (2015) Laparoscopic extraperitoneal para-aortic lymphadenectomy. Ecancermedicalscience 9: 573.

19. limuro Y, Deguchi Y, Ueda Y, Tanaka A, Iwasa Y, et al. (2002) Primary hepatic carcinoid tumor with metachronous lymph node metastasis after long-term follow up. J Gastroenterol Hepatol 17: 1119-1124.

20. Staren ED, Gould VE, Warren WH, Wool NL, Bines S, et al. (1988) Neuroendocrine carcinomas of the colon and rectum: a clinicopathologic evaluation. Surgery 104: 1080-1089.

21. Rabban JT, Lerwill MF, McCluggage WG, Grenert JP, Zaloudek CJ (2009) Primary ovarian carcinoid tumors may express CDX-2: a potential pitfall in distinction from metastatic intestinal carcinoid tumors involving the ovary. Int $J$ Gynecol Pathol 28: 41-48. 